\title{
Relationship marketing effectiveness in retailing: a contingency approach
}

Citation for published version (APA):

Odekerken-Schroder, G. J., de Wulf, K., \& Reynolds, K. E. (2000). Relationship marketing effectiveness in retailing: a contingency approach. METEOR, Maastricht University School of Business and Economics. METEOR Research Memorandum No. 036 https://doi.org/10.26481/umamet.2000036

Document status and date:

Published: 01/01/2000

DOI:

10.26481/umamet.2000036

Document Version:

Publisher's PDF, also known as Version of record

\section{Please check the document version of this publication:}

- A submitted manuscript is the version of the article upon submission and before peer-review. There can be important differences between the submitted version and the official published version of record.

People interested in the research are advised to contact the author for the final version of the publication, or visit the DOI to the publisher's website.

- The final author version and the galley proof are versions of the publication after peer review.

- The final published version features the final layout of the paper including the volume, issue and page numbers.

Link to publication

\footnotetext{
General rights rights.

- You may freely distribute the URL identifying the publication in the public portal. please follow below link for the End User Agreement:

www.umlib.nl/taverne-license

Take down policy

If you believe that this document breaches copyright please contact us at:

repository@maastrichtuniversity.nl

providing details and we will investigate your claim.
}

Copyright and moral rights for the publications made accessible in the public portal are retained by the authors and/or other copyright owners and it is a condition of accessing publications that users recognise and abide by the legal requirements associated with these

- Users may download and print one copy of any publication from the public portal for the purpose of private study or research.

- You may not further distribute the material or use it for any profit-making activity or commercial gain

If the publication is distributed under the terms of Article $25 \mathrm{fa}$ of the Dutch Copyright Act, indicated by the "Taverne" license above, 


\title{
Relationship Marketing Effectiveness in Retailing: A Contingency Approach
}

\author{
Gaby Odekerken-Schröder \\ Kristof de Wulf \\ Kristy E. Reynolds
}

\section{MAXX WORKING PAPER SERIES}

\author{
Maastricht Academic Center \\ for research in Services
}

Maxx 


\section{RELATIONSHIP MARKETING EFFECTIVENESS IN RETAILING:}

\section{A CONTINGENCY APPROACH}

Relationship marketing is not effective in every situation or context. This study investigates the impact of four categories of potential contingency factors on relationship marketing effectiveness in a retail context: demographic characteristics of the consumer (age and gender), personal values of the consumer (social recognition and social affiliation), shopping-related characteristics (product category involvement, store relationship proneness, and shopping enjoyment), and contextual characteristics (industry and country). The data relate to more than 1,700 mall intercept personal interviews conducted not only in the United States, but also in two western European countries (the Netherlands and Belgium), covering a wide variety of food and apparel retailers. The results indicate that relationship marketing efforts are relatively more effective if they are directed at consumers who are young and female, have a high need for social recognition and social affiliation, and show high levels of product category involvement, store relationship proneness, and shopping enjoyment. In addition, apparel stores seem to offer better relationship marketing opportunities than supermarkets. This is important for retailers as it offers a framework to optimize the allocation of their relationship marketing budgets. 


\section{INTRODUCTION}

Retail markets are increasingly characterized by global competition, market fragmentation, crowded retail environments, undifferentiated product and pricing offerings, shortened product life cycles, and more demanding and knowledgeable consumers (Wakefield and Baker 1998). Driven by these evolutions, retailers are finding it necessary to continually seek out products, processes, and technologies that increase store loyalty (Woodruff 1997). As the economic benefits of store loyalty are at the basis of explaining differences in retail performance, relationship marketing has become the prime imperative for many retailers to achieve sustainable superior profits (Anderson, Fornell, and Rust 1997; Kalwani and Narayandas 1995).

Despite the increased attention for relationship marketing practices, various scholars consider relationship marketing efforts not to be effective in every situation or context (e.g., Barnes 1997). Not every exchange has the potential to grow into a relationship and a thorough cost-benefit analysis is required before retailers make a decision to invest in relationship marketing (Houston and Gassenheimer 1987). Different scholars emphasized that retailers' resources could be misallocated or even wasted as a result of automatically applying a relationship marketing strategy in every situation (Bendapudi and Berry 1997; Christy, Oliver, and Penn 1996). Moreover, undifferentiated relationship marketing approaches could cause consumers to become disappointed or to perceive relationship marketing efforts as intrusive (Krapfel, Salmond, and Spekman 1991). Low (1997) even indicated that, under certain conditions, parties should actively and consciously play the market, seek out opportunities, and develop an opportunistic mentality. However, to the authors' knowledge, no empirical evidence has yet been compiled on contingency factors potentially curbing or strengthening the effects of relationship marketing. 
In response to this, the prime interest of this study is to assess the impact of four types of contingency variables on relationship marketing effectiveness: demographic characteristics of the consumer (age and gender), personal values of the consumer (social recognition and social affiliation), shopping-related characteristics (product category involvement, store relationship proneness, and shopping enjoyment), and contextual characteristics (industry and country). First, we discuss the main literature relevant for the objectives of the study and introduce the hypotheses investigated. Second, we outline the method used for empirical validation and examine the quality of the model presented. Finally, the results are presented, followed by the discussion and implications.

\section{THEORETICAL BACKGROUND AND HYPOTHESES}

According to Bendapudi and Berry (1997, p. 31), "a contingency approach to relationship marketing involves understanding when and why customers are most receptive to relationship maintenance". Inspired by their ideas, we assess to which extent relationship marketing effectiveness varies with a broad range of "when and why" variables. First, we define the concept of relationship marketing effectiveness and introduce our und erlying conceptual model. Second, we discuss the nature of all contingency factors hypothesized to influence relationship marketing effectiveness and present the research hypotheses.

\section{Relationship Marketing Effectiveness}

Bagozzi (1995) explicitly criticized relationship marketing literature for neglecting to conceptualize what a marketing relationship is. We define a relationship between a consumer and a store as "one or more exchanges between a consumer and a store that are perceived by the 
consumer as being interrelated to potential past and future exchanges with the store". This definition has important implications for our delineation of relationship marketing effectiveness. First, Hinde (1979, p. 15) noticed that "to discuss how long we must talk to a stranger in the street before we can properly say we have a relationship with him would not be very constructive". In other words, it is impossible to determine where a discrete exchange goes over in a relationship. In line with Webster (1992), we regard one exchange as a necessary and sufficient condition for a relationship to exist as it marks the beginning of a continuum of relationships. Therefore, research on relationship marketing effectiveness should not focus at discovering whether a relationship exists but rather at the extent to which it exits. Second, we agree with Barnes (1997) who postulated that no relationship is operating unless the consumer perceives that it is. Nevertheless, the consumer's perspective in evaluating buyer-seller relationships has been largely under-researched (Sheth and Parvatiyar 1995). As a result, we argue for the need to approach relationship marketing effectiveness from the viewpoint of the consumer. Third, our definition of a relationship assumes that a consumer perceives exchanges with a store to be interrelated to potential past and future exchanges (Iacobucci and Ostrom 1996). Consequently, relationship marketing effectiveness relates to a cumulative evaluation of all exchanges to date as opposed to a transaction-specific evaluation.

In this study, we assess relationship marketing effectiveness by investigating whether consumers perceive stores' efforts aimed at increasing store loyalty and whether they appreciate perceived efforts. This is based on the idea that relationship marketing efforts are not deemed to be effective in case such efforts are not perceived or, if perceived, not valued by the consumer. Both perception and appreciation of relationship marketing efforts are modeled in Figure 1. We assume that consumers perceive relationship marketing efforts in the case of a positive 
relationship between these efforts and the store's level of customer retention orientation. A consumer's appreciation of such efforts is expressed by a positive relationship between customer retention orientation and relationship outcomes. Figure 1 depicts the interrelationships between four relationship marketing efforts (communication, differentiation, personalization, and rewarding), a store's customer retention orientation, and three relationship outcomes (relationship satisfaction, relationship commitment, and behavioral loyalty). Each construct is briefly discussed below.

Insert Figure 1 about here

Elaborating on the work of Gwinner, Gremler, and Bitner (1998), this study distinguishes four types of relationship marketing efforts. First, we define communication as “a consumer's perception of the extent to which a store keeps its regular customers informed through direct communication media" (e.g., Dwyer, Schurr, and Oh 1987). By conveying interest in the consumer, communication is often considered to be a necessary condition for effective relationships (Duncan and Moriarty 1998). Second, we regard differentiation as "a consumer's perception of the extent to which a store treats and serves its regular customers differently from its non-regular customers" (e.g., Gwinner, Gremler, and Bitner 1998). Sheth and Parvatiyar (1995, p. 264) referred to the importance of differentiation by recognizing that "implicit in the idea of relationship marketing is consumer focus and consumer selectivity - that is, all consumers do not need to be served in the same way". Third, we consider personalization as "a consumer's perception of the extent to which a store interacts with its regular customers in a warm and personal way" (cf. Metcalf, Frear, and Krishnan 1992). The importance of personal exchanges between consumers and store personnel in influencing relationship outcomes should not be surprising given that relationships are inherently social processes (Beatty et al. 1996). 
Finally, we distinguish between intangible rewards, meaning the relationship marketing efforts previously described, and tangible rewards, meaning "a consumer's perception of the extent to which a store offers tangible benefits such as pricing or gift incentives to its regular customers in return for their loyalty". For example, trying to earn points - on such things as grocery purchases, hotel stays, movie tickets, and car washes - would help consumers to remain loyal, regardless of service enhancements or price promotions of competitors (Sharp and Sharp 1997).

Customer retention orientation plays a key mediating role in our assessment of relationship marketing effectiveness. We define customer retention orientation as "a consumer's overall perception of the extent to which a store actively makes efforts that are intended to contribute to the customer value of its regular customers". While our particular term, "customer retention orientation," is new in relationship marketing literature, we believe it builds upon related concepts, such as "relational selling behavior" in a customer-salesperson relationship context (Beatty et al. 1996; Crosby, Evans, and Cowles 1990), "relationship quality" in business markets (Scheer and Stern 1992), and even the concept of "market orientation," defined as strategic activities directed at delivering superior value to the customer (Kohli and Jaworski 1990; Narver and Slater 1990). While our concept has some ground in common with these constructs, we believe it differs substantially in several ways. First, the concept of customer retention orientation goes beyond the limited scope of salespersons' efforts emphasized in studies investigating relational selling behavior. Second, while relationship quality assesses the extent to which a consumer experiences a relationship with a store, customer retention orientation focuses at factors determining the quality of this relationship. Third, consumer perceptions are at the basis of customer retention orientation (i.e., a consumer's perspective), 
whereas the construct of market orientation is based upon a company's internal assessment of customer value delivery (i.e., ultimately a store's perspective).

Models that theorize attitudinal as well as behavioral relationship outcomes have strong precedence in relationship marketing studies. Frequently reported attitudinal outcomes include relationship satisfaction and relationship commitment (e.g., Garbarino and Johnson 1999; Geyskens, Steenkamp, and Kumar 1999). We define relationship satisfaction as “a consumer's affective state resulting from an overall appraisal of the relationship with the store" (cf. Anderson and Narus 1984). Relationship commitment is defined as “a consumer's enduring desire to continue a relationship with a store accompanied by the willingness to make efforts at maintaining it" (cf. Morgan and Hunt 1994). As Sharp and Sharp (1997) explicitly stated that the effectiveness of relationship marketing efforts should be evaluated in terms of the behavioral changes they create, we added behavioral loyalty as a behavioral outcome of relationships in line with Dick and Basu (1994).

\section{Contingency Factors in Relationship Marketing}

This study examines the potential moderating impact of four types of variables on relationship marketing effectiveness: demographic characteristics of the consumer (age and gender), personal values of the consumer (social recognition and social affiliation), shoppingrelated characteristics (product category involvement, store relationship proneness, and shopping enjoyment), and contextual characteristics (industry and country). Each of these is described in turn.

Demographic characteristics. Demographic variables are generally considered to influence store patronage behavior and customer loyalty (Reichheld 1993). For instance, Miller 
and Granzin (1979) found demographics to be related to the benefits that consumers seek in their relationship with a store. Two demographic variables were included in this study: age and gender. With respect to age, it can be claimed that older people think and behave differently than younger people concerning marketing related phenomena (Wilkes 1992). Wakefield and Baker (1998) indicated that age may be a moderating factor affecting consumer response to retail environments. More specifically, several authors found support for the widely accepted theoretical assumption that older consumers rely relatively stronger on more heuristic or schemabased forms of processing (Cole and Balasubramanian 1993; Wilkes 1992; Yoon 1997). This is in line with Richardson, Jain, and Dick (1996) who found no support for their hypothesis that older shoppers are more likely to engage in detailed processing given their experience with shopping. This leads us to hypothesize that younger consumers perceive and appreciate relationship marketing efforts more than older consumers as young shoppers are more likely to process these efforts in detail. Hence, we formulate the following hypotheses:

- $\mathrm{H}_{1 \mathrm{a}}$ : Younger consumers perceive relationship marketing efforts more than older consumers $-\mathrm{H}_{1 \mathrm{~b}}$ : Younger consumers appreciate relationship marketing efforts more than older consumers With respect to gender, it is generally recognized that buying has traditionally been femaledominated (Kline and Wagner 1994). Some studies even indicated that 80 percent of the shoppers in department stores consist of women (Bellenger and Korgaonkar 1980). Gender is generally acknowledged to have a profound impact on response to marketing strategies. For example, Korgaonkar, Lund, and Price (1985) discovered that female consumers exhibit a stronger patronage behavior than male consumers. Also Fournier (1998) concluded that women have more and stronger interpersonal and brand relationships than men. Based upon this reasoning, we hypothesize that: 
- $\mathrm{H}_{2 \mathrm{a}}$ : Female consumers perceive relationship marketing efforts more than male consumers

- $\mathrm{H}_{2 b}$ : Female consumers appreciate relationship marketing efforts more than male consumers

Personal values. It is generally acknowledged that personal values underlie consumption behaviors (e.g., Kahle, Beatty, and Homer 1986). However, empirical research on the importance of personal values in retail shopping behavior is largely lacking (Shim and Eastlick 1998).

Following Shim and Eastlick's (1998) recent study on the role of personal values in affecting shopping attitudes and behavior, we assess the potential moderating role of social recognition and social affiliation on relationship marketing effectiveness. In line with Brock et al. (1998), we define social recognition as “a consumer's individual characteristic representing the desire of being well-respected by others". Social recognition is assumed to guide relationship development and to define the resulting type of relationship (Kirkpatrick and Davis 1994). Forman and Sriram (1991) claimed that some people engage in buyer-seller relationships in a search for human contact and social recognition. For example, being seen and recognized while shopping in exclusive stores may be a way to express pride for shoppers with strong needs for social recognition (Shim and Eastlick 1998). Therefore, relationship marketing efforts targeted at consumers with higher needs for social recognition can be expected to be more successful. This leads to the following hypotheses.

$-\mathrm{H}_{3 \mathrm{a}}$ : Consumers with a higher need for social recognition perceive relationship marketing efforts more than other consumers

- $\mathrm{H}_{3 \mathrm{~b}}$ : Consumers with a higher need for social recognition appreciate relationship marketing efforts more than other consumers

In line with Cheek and Buss (1981), we define social affiliation as "a consumer's individual characteristic representing the tendency to affiliate with others and to prefer being with others to 
remaining alone". Engaging in buyer-seller relationships might be one of the ways to satisfy the need for exchanges with other people (Forman and Sriram 1991). Shim and Eastlick (1998) argued that many people visit stores not only to acquire goods and services, but also to seek socializing benefits. Thus we postula te the following hypotheses:

- $\mathrm{H}_{4 \mathrm{a}}$ : Consumers with a higher need for social affiliation perceive relationship marketing efforts more than other consumers

$-\mathrm{H}_{4 \mathrm{~b}}$ : Consumers with a higher need for social affiliation appreciate relationship marketing efforts more than other consumers

Shopping-related characteristics. In addition to idiosyncratic personal values of consumers, we incorporated three domain-specific attitudes of consumers towards shopping as potential moderators of relationship marketing effectiveness: product category involvement, store relationship proneness, and shopping enjoyment. First, in line with Mittal (1995), we define product category involvement as "a consumer's enduring perceived importance of the product category based on the consumer's inherent needs, values, and interests". Researchers have suggested that individuals who are highly involved with the product category reveal a tendency to be more loyal (Dick and Basu 1994; King and Ring 1980). Christy, Oliver, and Penn (1996) stressed that highly-involved consumers provide a strong basis for extending the relationship. Consequently, approaches by the store, however well intentioned, could be regarded by the consumer as undesirable when the consumer's involvement is low (Christy, Oliver, and Penn 1996). Consequently, we hypothesize that:

- $\mathrm{H}_{5 \mathrm{a}}$ : Consumers revealing a higher level of product category involvement perceive relationship marketing efforts more than other consumers 
- $\mathrm{H}_{5 \mathrm{~b}}$ : Consumers revealing a higher level of product category involvement appreciate relationship marketing efforts more than other consumers

Second, we consider store relationship proneness as "a consumer's relatively stable and conscious tendency to engage in relationships with stores of a particular product category".

Despite its recognized importance, no study has yet investigated the potential moderating impact of consumers' proneness to engage in relationships with stores on relationship marketing effectiveness (Sheth and Parvatiyar 1995). Fournier, Dobscha, and Mick (1998, p. 42) recently pointed to this issue by stressing that "caught up in our enthusiasm for our information-gathering capabilities and for the potential opportunities that long-term engagements with customers hold, is it possible that we have forgotten that relationships take two?" As, by definition, relationshipprone consumers are most likely to develop relationships, we formulate the following two hypotheses:

- $\mathrm{H}_{6 \mathrm{a}}$ : Consumers revealing a higher level of store relationship proneness perceive relationship marketing efforts more than other consumers

- $\mathrm{H}_{6 \mathrm{~b}}$ :Consumers revealing a higher level of store relationship proneness appreciate relationship marketing efforts more than other consumers Finally, in line with Bellenger and Korgaonkar (1980), we define shopping enjoyment as “a consumer's individual characteristic representing the tendency to find shopping more enjoyable and to experience greater shopping pleasure than others". The construct of shopping enjoyment relates to the difference between hedonic and utilitarian shoppers. While utilitarian shoppers aim at accomplishing the consumption task, hedonic shoppers strive for fun and entertainment related to shopping (Beatty and Ferrell 1998; Hirschman and Holbrook 1982; Wakefield and Baker 1998). Bellenger and Korgaonkar (1980) proved that people who enjoy shopping hardly ever 
have a pre-planned purchase in mind, potentially reducing their desire to commit themselves to one specific store. Consequently, we hypothesize that consumers who lack shopping enjoyment are interested in relationships with stores as these relationships might mitigate their unpleasant shopping task. The following hypotheses are proposed:

$-\mathrm{H}_{7 \mathrm{a}}$ : Consumers revealing a lower level of shopping enjoyment perceive relationship marketing efforts more than other consumers

- $\mathrm{H}_{7 \mathrm{~b}}$ :Consumers revealing a lower level of shopping enjoyment appreciate relationship marketing efforts more than other consumers

Contextual characteristics. The type of country or industry retailers are operating in can be expected to influence the effectiveness of their relationship marketing efforts. First, this study is conducted not only in the United States, but also in two highly developed western European countries, the Netherlands and Belgium. According to Hofstede's (1980) classification of countries on the basis of cultural dimensions, the United States and the Netherlands closely resemble each other with respect to their level of "uncertainty avoidance". Belgium seriously deviates from the other two countries as Belgian consumers reveal much higher levels of uncertainty avoidance. Roth (1995, p. 165) stated that "uncertainty avoidance captures the cultural pattern of seeking stability, predictability, and low stress rather than change and new experiences ... People in high uncertainty avoidance cultures are risk averse, resistant to change and variety seeking, and have a low tolerance for ambiguity". As relationship marketing is generally believed to be more effective in situations characterized by uncertainty (Crosby, Evans, and Cowles 1990), we expect Belgian stores to be more successful in creating and maintaining consumer relationships as opposed to US and Dutch stores. Concluding, we hypothesize that: 
- $\mathrm{H}_{8 \mathrm{a}}$ : Belgian consumers perceive relationship marketing efforts more than US or Dutch consumers

- $\mathrm{H}_{8 \mathrm{~b}}$ : Belgian consumers appreciate relationship marketing efforts more than US or Dutch consumers

Second, two industries were subject to our investigation: food and apparel. In general, relationships are considered to have a larger growth potential in industries characterized by high degrees of social exchange (Berry 1995; Iacobucci and Ostrom 1996). Metcalf, Frear, and Krishnan (1992, p. 29) referred to social exchange as "the interpersonal relationships which exist between members of the buying and selling centers". In apparel stores, it is common practice to receive for example personal service, extra attention, and customized advice. This is in contrast to the more anonymous, standard self-service that is provided in a typical supermarket. As a result, we can safely assume that the level of social exchange is higher in apparel stores than in supermarkets. This results in the following hypotheses:

- $\mathrm{H}_{9 \mathrm{a}}$ : Consumers perceive relationship marketing efforts made by apparel stores more than relationship marketing efforts made by supermarkets

- $\mathrm{H}_{9 \mathrm{~b}}$ :Consumers appreciate relationship marketing efforts made by apparel stores more than relationship marketing efforts made by supermarkets

\section{METHOD}

Setting

This large-scale study is conducted in the food and apparel industries, covering a wide variety of retailers including discount stores, mass merchandisers, traditional department stores, as well as prestige stores. Relationship marketing is predominantly important in both industries 
as competition has gradually intensified over the years (Gutman and Mills 1982; Sirohi, McLaughlin, and Wittink 1998). In addition, we tested the role of contingency factors on relationship marketing effectiveness in three different countries, covering respondents from the United States, the Netherlands, and Belgium.

\section{Samples}

Mall intercept personal interviews were administered in the United States (food: N=231, apparel: $\mathrm{N}=230$ ), the Netherlands (food: $\mathrm{N}=337$, apparel: $\mathrm{N}=338$ ), and Belgium (food: $\mathrm{N}=289$, apparel: $\mathrm{N}=302)$. Samples were drawn from shopping mall visitors to obtain coverage on age (18 to 25 years, 26 to 40, 41 to 55, and 55 years and over), gender, and allocated share-of-wallet for the store reported on $(0-20 \%, 21-40 \%, 41-60 \%, 61-80 \%$, and $81-100 \%)$. These criteria are often mentioned to influence shopping attitudes and behavior (e.g., Carman 1970), so we consider them to be relevant for the study's objectives. We also sought even coverage over interviewing time of day (morning, early afternoon, and late afternoon) and interviewing day of week (Wednesday, Friday, and Saturday) so as to reduce possible shopping pattern biases. Across our samples, an average of $37 \%$ of the visitors who were approached participated.

\section{Procedure}

Participants were first asked whether they had ever made a purchase in the particular product category. If so, they were asked to indicate the names of five stores in which they usually bought food or apparel. Next, respondents indicated their approximate share-of-wallet for each store listed (measured on a continuous scale from $0 \%$ to 100\%) and the extent to which they felt they were a regular customer of each store (measured on a scale from 1 to 7). Finally, the 
interviewers selected a specific store to which the remaining questions were related, based upon the stated share-of-wallet. In order to increase internal validity, only those stores were included for which respondents indicated at least 4 on the 7-point scale measuring their "being a regular customer". The questions addressed all constructs included in the conceptual model and all contingency variables.

\section{Measure Development}

Focus groups were used to learn how consumers perceive stores' relationship marketing efforts and under which circumstances they appreciate such efforts. Four groups were organized in cooperation with a medium-sized Belgian retail clothing chain that provided a database containing detailed information on the purchasing history of its customers. Customers recruited for the focus groups were divided into four homogeneous groups: seven women disloyal to the clothing chain, seven loyal women, five men disloyal to the clothing chain, and four loyal men. Focus group discussions lasted between 1.5-2.0 hours. Participants were first asked open-ended questions about their own behavior with respect to shopping for clothing. Second, direct questions were posed. Finally, projective techniques were used during the remainder of the discussions (i.e., depth descriptions, photo-sorts). Participants received a monetary incentive in return for their cooperation. On basis of the focus groups, an initial pool of items intended to measure relationship marketing efforts was composed and qualitatively tested by a group of expert judges (four academics and three practitioners). Experts were provided with the definitions of the relationship marketing efforts and asked to classify each item to the most appropriate construct. Items improperly classified were reformulated or deleted. Items for 
measuring relationship outcomes and contingency factors were generated on basis of existing conceptual and empirical work. The measurement items are located in the Appendix.

Questionnaire Development

We pre-tested items for all constructs and contingency factors on a sample of 60 consumers via personal in-home interviews. The pre-test sample of consumers was evenly spread across age, gender, and country. We asked respondents to complete the questionnaire, after which they were asked to describe the meaning of each question, to explain their answer, and to state any problems they encountered while answering questions. Small adjustments to the questionnaire were made on basis of the pre-test.

Translation equivalence in the final questionnaire was aimed for by carrying out a back translation procedure. A native American who was fluent in Dutch first translated the original Dutch version of the questionnaire into English and a native Dutch speaker who was fluent in American English then retranslated the questionnaire into Dutch. The quality of the translation was evaluated by a mono-linguistic, native American on clarity and comprehensiveness of the translated questionnaire.

\section{Final Measures}

Final attempts at measure purification were conducted on a sample $(\mathrm{N}=371)$ drawn to resemble the eventual multi-country, multi-industry sample. First, we factored the items related to the conceptual model to investigate whether they correctly measured their intended constructs. Theoretically, it was likely that the latent constructs in this model would be correlated, so we applied an oblique rotation. We only retained items that minimally loaded 0.65 on the proper 
latent variable and maximally loaded 0.30 on the others so as to enhance the distinctiveness of the intended constructs. Second, in to order to verify to which extent all contingency factors could be considered as independent from each other, we conducted a principal components analysis using Varimax rotation to the items intended to measure social recognition, social affiliation, product category involvement, store relationship proneness, and shopping enjoyment. Nearly all items loaded at least 0.70 on their respective hypothesized factor, with a loading no larger than 0.40 on other constructs. The appendix contains all (7-point Likert) scales, organized by construct, with the corresponding Cronbach alpha values and item-total correlations. The measurement is clean, across scales, countries, and industries.

\section{MODEL EVALUATION}

In this section, we report on the characteristics of the data and we evaluate the overall and measurement models. Maximum likelihood estimation structural equations models were applied to our covariance matrices.

\section{Preliminary Data Analyses}

To enhance the stability of our covariance matrices, e.g., to help ensure their being positive definite, we employed case-wise deletion of missing values. We verified that sample compositions were not significantly different with regard to age and gender before and after case deletion. Even with these deletions, our sample sizes are substantially larger than those typically reported or those said to be required for stable estimation. We examined the data for skewness and kurtosis, but found only slight tendencies for either, not sufficient for transformations of responses which would introduce alternative problems, e.g., interpretability. We also assessed 
the data for the possible existence of univariate, bivariate, as well as multivariate outliers, using plots against normals, bivariate scatter plots, and Mahalanobis distance measures respectively. So few of the observations $(<1 \%)$ could be classified as outliers that we retained them for subsequent data analysis, because we believed both that our samples were large enough to envelope a few extreme data points and that such outliers were nevertheless representative of some segment of the target consumers.

\section{Overall Model Evaluation}

The chi-squares in each country for each industry are all significant, a finding not unusual with large sample sizes (Doney and Cannon 1997). The European samples reveal ratios of chisquare to degrees of freedom that are acceptable, ranging from 2.23 to 2.72 . In the US, these values are slightly higher with 3.16 for the food sample and 3.10 for the apparel sample. While the values of GFI (ranging from 0.78 to 0.88 ) and AGFI (ranging from 0.72 to 0.85 ) are somewhat lower than those of CFI (ranging from 0.89 to 0.94 ), this result is mainly due to the former measures being more easily affected by sample size. In general, the indicated fits are acceptable, including for the RMSEA (ranging from 0.060 to 0.097 ). Given the adequacy of these batteries of overall goodness-of-fit indices and given the fact that the model was developed on theoretical bases, no re-specifications of the model were made.

\section{Measurement Model Evaluation}

We assessed the quality of the measurement models in each country for each industry on unidimensionality, convergent validity, reliability, and discriminant validity. Evidence for the unidimensionality of each construct included the appropriate items loading at least 0.65 on their 
respective hypothesized factor, with a loading no larger than 0.30 on other constructs.

Convergent validity was supported by good overall model fits, all loadings being significant $(\mathrm{p}<$ 0.01), and nearly all $\mathrm{R}^{2}$ exceeding 0.50 (Hildebrandt 1987). Reliability was indicated by Cronbach alphas all exceeding 0.70 . Moreover, all of the composite reliability measures were at least 0.75, exceeding Bagozzi and Yi’s (1988) minimum values of 0.60. Discriminant validity was tested in a series of nested confirmatory factor model comparisons in which correlations between latent constructs were constrained to 1 (each of the 24 off-diagonal elements constrained and the model re-estimated in turn), and indeed chi-square differences were significant for all model comparisons $(\mathrm{p}<0.01)$ in all samples. In addition, the average percentage of variance extracted for each construct was greater than 0.50 (i.e., all constructs met this criterion except for relationship commitment in the Belgian (0.48) apparel sample). In sum, the measurement models are clean, with evidence for unidimensionality, convergent validity, reliability, and discriminant validity, which allowed proceeding to the assessment of moderating effects in the structural models.

\section{RESULTS}

The main objective of our study is to assess the moderating influences of a broad range of contingency variables on relationship marketing effectiveness. We tested these moderating effects via multi-group analysis, splitting the samples into sub-samples according to whether consumers scored high or low on the moderating variables to ensure within-group homogeneity and between-group heterogeneity. In the "equal" models, all paths of the structural model were set equal across sub-samples. In the free models, all paths were constrained to be equal across sub-samples, except for the links potentially affected by the moderator variable. Differences in 
chi-square values between models determine whether the contingency factor acts as a moderating variable. A significant decrease in chi-square from the equal model to a model in which one relationship is set free implies that the moderator variable has a significant influence on that relationship.

\section{Demographic Characteristics}

Age. Table 2 reveals that age significantly moderates the impact of relationship marketing efforts on customer retention orientation (significant in $13 \%$ of the paths examined) and the impact of customer retention orientation on relationship outcomes (significant in $22 \%$ of the paths examined). For those relationships that were moderated, Table 6 reveals that within-group path coefficients were consistently lower in the sub-sample representing older consumers than in the sub-sample including younger consumers. Only one exception was found: in the Dutch apparel sample, a store's customer retention orientation yielded a greater impact on relationship commitment for older consumers. The multi-group results related to age imply that the effectiveness with which stores can build consumer relationships increases when they target relatively younger consumers. As moderating effects could be detected for several paths examined, these findings partially support $\mathrm{H}_{1 \mathrm{a}}$ and $\mathrm{H}_{1 \mathrm{~b}}$.

Gender. From Table 2, we can derive that women perceive relationship marketing efforts more than men (significant in $13 \%$ of the paths examined) and that they also appreciate these efforts more in comparison with men (significant in $17 \%$ of the paths examined). For those relationships that were moderated, Table 6 reveals that within-group path coefficients were consistently lower in the sub-sample representing male consumers than in the sub-sample including female consumers. Only in the US apparel sample, it appeared that men became more 
easily committed to a store as a result of this store's customer retention orientation than women. These results draw our attention to the fact that female consumers are more receptive to relationship marketing efforts. As moderating effects could be detected for several paths examined, these findings partially support $\mathrm{H}_{2 \mathrm{a}}$ and $\mathrm{H}_{2 b}$.

\section{Personal Values}

Social recognition. Table 3 shows that only one path supports our hypothesis that people with a high need for social recognition are more sensitive to noticing relationship marketing efforts than people with a low need for social recognition (significant in $4 \%$ of the paths examined). We even found counter-evidence for hypothesis $\mathrm{H}_{3 \mathrm{a}}$ as consumers revealing a high need for social recognition had more difficulties recognizing store efforts as efforts aimed at increasing their loyalty. Nevertheless, the data show that people with a high need for social recognition represent an interesting market segment as stores' retention efforts directed at this segment yield a greater impact on satisfaction, commitment, and behavioral loyalty (significant in $33 \%$ of the paths examined). As a result, hypothesis $\mathrm{H}_{3 \mathrm{~b}}$ was partially confirmed as several within-group path coefficients were consistently higher in the sub-sample representing consumers with a high need for social recognition than in the sub-sample including consumers with a low need for social recognition.

Social affiliation. Table 3 indicates that consumers with a strong desire for social contact have weaker perceptions of relationship marketing efforts as elements of a store's customer retention strategy than consumers exhibiting a low need for social affiliation (significant in $8 \%$ of the paths examined). However, more socially inclined consumers do appreciate these efforts more strongly as they consistently show higher levels of satisfaction, commitment, and 
behavioral loyalty for the same level of customer retention orientation (significant in $28 \%$ of the paths examined). These results partially contradict hypothesis $\mathrm{H}_{4 \mathrm{a}}$ and provide partial support for hypothesis $\mathrm{H}_{4 b}$.

\section{Shopping-Related Characteristics}

Product category involvement. Table 4 suggests that highly involved consumers have a stronger tendency to perceive relationship marketing efforts (significant in $4 \%$ of the paths examined) and to simultaneously appreciate these efforts more strongly (significant in 17\% of the paths examined). For all paths that were moderated, Table 8 reveals that within-group path coefficients were consistently higher in the sub-sample representing highly involved consumers than in the sub-sample including less involved consumers. This provides support for our hypotheses $\mathrm{H}_{5 \mathrm{a}}$ and $\mathrm{H}_{5}$.

Store relationship proneness. Consumers characterized by a high level of relationship proneness tend to perceive a store's relationship marketing efforts stronger than their counterparts (significant in $4 \%$ of the paths examined, see Table 4). The same reasoning holds for the appreciation of these efforts (significant in 39\% of the paths examined). These results imply that relationship-prone consumers are attractive targets for stores to direct relationship marketing efforts at. This supports hypotheses $\mathrm{H}_{6 \mathrm{a}}$ and $\mathrm{H}_{6 \mathrm{~b}}$.

Shopping enjoyment. We found mixed evidence for our hypothesis $\mathrm{H}_{7 \mathrm{a}}$ that people who enjoy shopping will be less sensitive to perceiving relationship marketing efforts than people who dislike shopping. Table 4 indicates that significant moderating effects occur in $17 \%$ of the paths going from relationship marketing efforts to customer retention orientation. No consistent patterns could be detected for the changes in within-group path coefficients (see Table 8). 
Nevertheless, unequivocal evidence was found for $22 \%$ of the paths from customer retention orientation to relationship outcomes, indicating that consumers who like shopping tend to value a store's retention efforts more than consumers considering shopping more as a necessity. This provides counter-support for hypothesis $\mathrm{H}_{7 \mathrm{~b}}$.

\section{Contextual Characteristics}

Country. While significant differences between countries were found (significant in $36 \%$ of the paths examined), no consistent pattern emerged. While, according to our hypotheses, we expected relationship marketing to be more effective in the Belgian samples, this was not the case for each path as shown in Table 9. Consequently, hypotheses $\mathrm{H}_{8 \mathrm{a}}$ and $\mathrm{H}_{8 \mathrm{~b}}$ were not supported.

Industry. Consistent with hypotheses $\mathrm{H}_{9 \mathrm{a}}$ and $\mathrm{H}_{9 \mathrm{~b}}$, our data indicate that relationship marketing is more effective in an apparel context as opposed to a food context (significant in $33 \%$ of the paths examined). Only in the Belgian samples, supermarkets were found to be more effective in relationship marketing than apparel stores. As a result, partial support was found for hypotheses $\mathrm{H}_{9}$ and $\mathrm{H}_{9 b}$.

\section{DISCUSSION AND IMPLICATIONS}

The prime interest of this study was to assess whether relationship marketing effectiveness is dependent upon various types of contingency factors. Despite the recognized importance of this objective (Barnes 1997; Christy, Oliver, and Penn 1996; Kalwani and Narayandas 1995), no study has ever tackled this issue before. Our study provides the first empirical evidence demonstrating the moderating role of age, gender, social recognition, social 
affiliation, product category involvement, store relationship proneness, shopping enjoyment, and industry on the effectiveness of relationship marketing efforts. It emphasizes that stores should not lose sight of the importance of consumer- and industry-related factors in shaping customer loyalty. No matter how much trouble a retailer goes through in order to increase customer loyalty, such efforts can be seriously tempered or strengthened. Consequently, retailers should not only optimize their efforts towards consumers, but also pay equal attention to finding those consumers who will perceive and appreciate these efforts. Understanding this is critical for retailers who increasingly aim at targeting individual consumers instead of applying mass marketing approaches.

While many retailers are making their first moves in implementing relationship marketing strategies, hardly any efforts to target these strategies towards specific consumer segments are being made (Barnes 1997). The results of our study indicate that segmenting relationship marketing efforts does pay off in terms of increased effectiveness. Targeting relationship marketing efforts at suitable consumer segments may be the most cost effective method to keep existing customers.

While demographic variables were often found to be ineffective with respect to their systematic impact on variables of interest such as consumer choice (Kim, Srinivasan, and Wilcox 1999; Richardson, Jain, and Dick 1996), this study clearly shows that age and gender provide guidance to retailers in allocating their relationship marketing resources. First, it appears that young consumers react more favorably to retailers' efforts aimed at enhancing customer loyalty. This could support the underlying thought that younger shoppers engage in more elaborate processing of retailer-originated stimuli (Cole and Balasubramanian 1993; Wilkes 1992; Yoon 1997). As more and more retailers face aging market segments (Wilkes 1992; Yoon 1997), the 
challenge of tomorrow's retailers is to find appropriate ways to earn the loyalty of older consumers. Moreover, our results suggest that it is worthwhile for retailers to start customerbonding practices when their target population is relatively young in order to encourage "lifetime" commitment.

Second, female consumers proved to be more sensitive to loyalty efforts as opposed to male consumers. This provides additional support to Fournier's (1998) conclusion that women reveal more intense interpersonal and brand relationships. Again, this may have important implications for retailers as males are doing more of the shopping than was the case in previous generations and in categories that traditionally were not part of their shopping domain, such as grocery and clothing (Evans, Christiansen, and Gill 1996). As a result, stores are urged to increase their appeal to men in terms of the way they try to stimulate store loyalty.

An interesting observation was made with respect to the moderating impact of two personal values. While people with a higher need for social recognition and social affiliation appreciate a store's customer relationship orientation relatively stronger, it is more difficult for a retailer to make them aware of the fact that relationship marketing efforts are intended to stimulate customer loyalty. At first sight, this seems surprising. However, strong empirical support exists for a comparable phenomenon in the literature on customer satisfaction. Similar to the notion that consumers with higher expectations are more difficult to satisfy (Oliver 1997), consumers with a higher need for social values seem to be more demanding towards a retailer's relationship marketing efforts. It appears that they do not explicitly relate such efforts to a store's customer loyalty initiatives. This has important implications for retailing practice. Retailers targeting consumer segments that are sensitive to the social values examined (expressed by advertising images, salespeople, and in-store atmospherics in communication messages), should 
explicitly stress their objective of creating customer loyalty in communicating the efforts they make. If they do not, they run the risk of wasting valuable resources invested in launching relationship marketing efforts.

Also shopping-related characteristics were found to play a significant role in strengthening or weakening relationship marketing effectiveness. First, the results show that store relationship proneness repeatedly mitigates relationship marketing effectiveness, providing initial support for the ideas expressed by Bendapudi and Berry (1997) and Barnes (1997). This might be explained by the fact that relationship-prone consumers are more sensitive to a store's efforts directed at them (cf. Dwyer, Schurr, and Oh 1987). In addition to more traditional segmentation criteria such as demographic or value-related characteristics, retailers can benefit from segmenting customers according to store relationship proneness. It offers huge potential as it is directly related to the objective of creating customer loyalty. A simple approach might be to integrate additional questions measuring relationship proneness when consumers fill out the information form underlying many customer loyalty cards.

Second, the data suggest that consumers with a higher degree of product category involvement are more influenced by a store's relationship marketing efforts (e.g., consistent with Solomon et al. 1985). Leuthesser (1997) pointed out that a buyer's stake in a relationship with a seller tends to be higher with greater involvement in the product category. Our data then might be reasonably interpreted as higher stakes in a relationship, causing consumers to appreciate a store's efforts more strongly. Segmenting consumers according to levels of product category involvement would affect expected share-of-market and share-of-customer given that involved consumers have a higher tendency to remain loyal to one store. Third, contrary to the findings of Bellenger and Korgaonkar (1980) and Forsythe, Butler, and Schafer (1990), people who enjoy 
shopping value enduring relationships with a store. The fact that consumers have more fun in shopping might explain their increased sensitivity towards various shopping-related impulses, including attempts to stimulate customer loyalty. A lesson to be drawn from this is that stores should not persistently confront people who dislike shopping with loyalty initiatives as this might work in the opposite direction.

Finally, we evaluated the role of two context-related characteristics. First, using Hofstede's (1980) uncertainty avoidance as a potential explanation for country differences in relationship marketing effectiveness proved not to be successful. This might well be attributed to the fact that uncertainty avoidance plays a lesser role in the consumer industries investigated. In general, buyers and sellers are less dependent upon each other in consumer contexts as opposed to business-to-business contexts. While consumers can easily switch sellers given their low idiosyncratic investments, they can hardly exert power on these sellers given their relatively low purchase size. Business-to-business relationships are often characterized by struggles for power, domination, and control. In contrast, consumers generally have difficulties exerting power over marketers because they only represent a fraction of a seller's business (Fischer and Bristor 1994).

Second, our data suggest that relationship marketing is more effective in the apparel industry than in the food industry. This might be explained by Berry's (1995) and Iacobucci and Ostrom's (1996) view that industries characterized by high degrees of social exchange have more relationship potential. Our result empirically validates Christy, Oliver, and Penn's (1996) idea that not all product-market combinations share the same level of relationship friendliness. It demonstrates the necessity for retailers to assess whether their industry is characterized by a promising level of relationship friendliness, limiting the risk of misdirecting critical relationship marketing resources. 


\section{REFERENCES}

Anderson, Eugene W., Claes Fornell, and Roland T. Rust (1997), Customer Satisfaction, Productivity, and Profitability: Differences Between Goods and Services, Marketing Science, 16 (2). 129-145.

Bagozzi, Richard P. (1995), Reflections on Relationship Marketing in Consumer Markets, Journal of the Academy of Marketing Science, 23 (4). 272-277.

---- and Youjae Yi (1988), On the Evaluation of Structural Equation Models, Journal of the Academy of Marketing Science, 16 (Spring). 74-94.

Barnes, James G. (1997), Closeness, Strength, and Satisfaction: Examining the Nature of

Relationships between Providers and Financial Services and Their Retail Customers, Psychology and Marketing, 14 (8). 765-790.

Beatty, Sharon E., James E. Coleman, Kristy Ellis Reynolds, and Jungki Lee (1996), CustomerSales Associate Retail Relationships, Journal of Retailing, 72 (3). 223-247.

---- and M. Elizabeth Ferrell (1998), Impulse Buying: Modeling Its Precursors, Journal of Retailing, 74 (2). 169-191.

Bellenger, Danny N. and Pradeep K. Korgaonkar (1980), Profiling the Recreational Shopper, Journal of Retailing, 56 (3). 77-92.

Bendapudi, Neeli and Leonard L. Berry (1997), Customers' Motivations for Maintaining Relationships With Service Providers, Journal of Retailing, 73 (1). 15-37.

Berry, Leonard L. (1995), Relationship Marketing of Services - Growing Interest, Emerging Perspectives, Journal of the Academy of Marketing Science, 23 (4). 236-245.

Brock, Douglas M., Erwin G. Sarason, Hari Sanghvi, and Regan A.R. Gurung (1998), The Perceived Acceptance Scale: Development and Validation, Journal of Social and Personal Relationships, 15 (1). 5-21.

Carman, James M. (1970), Correlates of Brand Loyalty: Some Positive Results, Journal of Marketing Research, 7 (1). 67-76.

Cheek, Jonathan M. and Arnold H. Buss (1981), Shyness and Sociability, Journal of Personality and Social Psychology, 41 (2). 330-339.

Christy, Richard, Gordon Oliver, and Joe Penn (1996), Relationship Marketing in Consumer Markets, Journal of Marketing Management, 12. 175-187. 
Cole, Catherine A. and Siva K. Balasubramanian (1993), Age Differences in Consumers' Search for Information: Public Policy Implications, Journal of Consumer Research, 20 (June). 157-169.

Crosby, Lawrence A., Kenneth R. Evans, and Deborah Cowles (1990), Relationship Quality in Services Selling: An Interpersonal Influence Perspective, Journal of Marketing, 54 (3). 6881.

Dick, Alan S. and Kunal Basu (1994), Customer Loyalty: Toward an Integrated Conceptual Framework, Journal of the Academy of Marketing Science, 22 (2). 99-113.

Doney, Patricia M. and Joseph P. Cannon (1997), An Examination of the Nature of Trust in Buyer-Seller Relationships, Journal of Marketing, 61 (2). 35-51.

Duncan, Tom and Sandra E. Moriarty (1998), A Communication-Based Marketing Model for Managing Relationships, Journal of Marketing, 62 (2). 1-13.

Dwyer, F. Robert, Paul H. Schurr, and Sejo Oh (1987), Developing Buyer-Seller Relationships, Journal of Marketing, 51 (2). 11-27.

Fischer, Eileen and Julia Bristor (1994), A Feminist Poststructuralist Analysis of the Rhetoric of Marketing Relationships, International Journal of Research in Marketing, 11 (4). 317-331. Forman, Andrew M. and Ven Sriram (1991), The Depersonalization of Retailing: Its Impact on The "Lonely" Consumer, Journal of Retailing, 67 (2). 226-243.

Forsythe, Sandra, Sara Butler, and Rober Schafer (1990), Surrogate Usage in the Acquisition of Women's Business Apparel, Journal of Retailing, 66 (Winter). 446-469.

Fournier, Susan (1998), Consumers and Their Brands: Developing Relationship Theory in Consumer Research, Journal of Consumer Research, 24 (2). 343-373.

----, Susan Dobscha, and David Glen Mick (1998), Preventing the Premature Death of Relationship Marketing, Harvard Business Review, (January-February). 42-44. Garbarino, Ellen and Mark S. Johnson (1999), The Different Roles of Satisfaction, Trust, and Commitment in Customer Relationships, Journal of Marketing, 63 (April). 70-87.

Geyskens, Inge, Jan-Benedict E.M. Steenkamp, and Nirmalaya Kumar (1999), A Meta-Analysis of Satisfaction in Marketing Channel Relationships, Journal of Marketing Research, 36 (May). 223-238. 
Gutman, Jonathan and Michael K. Mills (1982), Fashion Life Style, Self-Concept, Shopping Orientation, and Store Patronage: An Integrative Analysis, Journal of Retailing, 58 (2). 64 86.

Gwinner, Kevin P., Dwayne D. Gremler, and Mary Jo Bitner (1998), Relational Benefits in Services Industries: The Customer's Perspective, Journal of the Academy of Marketing Science, 26 (2). 101-114.

Hildebrandt, Lutz (1987), Consumer Retail Satisfaction in Rural Areas: A Reanalysis of Survey Data, Journal of Economic Psychology, 8 (1). 19-42.

Hinde, Robert A. (1979), Towards Understanding Relationships. London, UK: Academic Press. Hirschman, Elizabeth C. and Morris B. Holbrook (1982), Hedonic Consumption: Emerging Concepts, Methods, and Propositions, Journal of Marketing, 46 (3). 92-101.

Hofstede, Geert (1980), Culture's Consequences: International Differences in Work-Related Values, in Cross Cultural Research and Methodology Series, volume 5, Walter J. Lonner and John W. Berry (Eds.), Beverly Hills: Sage Publications.

Houston, Franklin S. and Jule B. Gassenheimer (1987), Marketing and Exchange, Journal of Marketing, 51 (4). 3-18.

Iacobucci, Dawn and Amy L. Ostrom (1996), Commercial and Interpersonal Relationships;

Using the Structure of Interpersonal Relationships to Understand Individual-to-Individual, Individual-to-Firm, and Firm-to-Firm Relationships in Commerce, International Journal of Research in Marketing, 13 (1). 53-72.

Kahle, Lynn R., Sharon E. Beatty, and Pamela Homer (1986), Alternative Measurement Approaches to Consumer Values: The List of Values (LOV) and Values and Lifestyle (VALS), Journal of Consumer Research, 13 (December). 405-409.

Kalwani, Manohar U. and Narakesari Narayandas (1995), Long-Term Manufacturer-Supplier Relationships: Do They Pay Off for Supplier Firms?, Journal of Marketing, 59 (January). $1-16$.

Kim, Byung-Do, Kannan Srinivasan, and Ronald T. Wilcox (1999), Identifying Price Sensitive Consumers: The Relative Merits of Demographic vs. Purchase Pattern Information, Journal of Retailing, 75 (2). 173-193.

King, Charles W. and Lawrence J. Ring (1980), Market Positioning Across Retail Fashion Institutions: A Comparative Analysis of Store Types, Journal of Retailing, 56 (1). 37-55. 
Kirkpatrick, L.A. and K.E. Davis (1994), Attachment Style, Gender, and Relationship Stability:

A Longitudinal Analysis, Journal of Personality and Social Psychology, 66. 502-512.

Kline, Barbara and Janet Wagner (1994), Information Sources and Retail Buyer Decision-

Making: The Effect of Product-Specific Buying Experience, Journal of Retailing, 70 (1). 75-88.

Kohli, Ajay K. and Bernard J. Jaworski (1990), Market Orientation: The Construct, Research Propositions, and Managerial Implications, Journal of Marketing, 54 (2). 1-18.

Korgaonkar, Pradeep K., Daulat Lund, and Barbara Price (1985), A Structural Equations

Approach Toward Examination of Store Attitude and Store Patronage Behavior, Journal of Retailing, 61 (2). 39-60.

Krapfel, Robert E., Deborah Salmond, and Robert Spekman (1991), A Strategic Approach to Managing Buyer-Seller Relationships, European Journal of Marketing, 25 (9). 22-37. Leuthesser, Lance (1997), Supplier Relational Behavior: An Empirical Assessment, Industrial Marketing Management, 26 (3). 245-254.

Low, Brian Koon Huat (1997), Long-Term Relationship in Industrial Marketing - Reality or Rhetoric?, Industrial Marketing Management, 25 (1). 23-35.

Metcalf, Lynn E., Carl R. Frear, and R. Krishnan (1992), Buyer-Seller Relationships: An Application of the IMP Interaction Model, European Journal of Marketing, 26 (2). 27-46.

Miller, Kenneth E. and Kent L. Granzin (1979), Simultaneous Loyalty and Benefit Segmentation of Retail Store Customers, Journal of Retailing, 55 (Spring). 47-60.

Mittal, Banwari (1995), A Comparative Analysis of Four Scales of Consumer Involvement, Psychology and Marketing, 12 (7). 663-682.

Morgan, Robert M. and Shelby D. Hunt (1994), The Commitment-Trust Theory of Relationship Marketing, Journal of Marketing, 58 (3). 20-38.

Narver, John C. and Stanley F. Slater (1990), The Effect of a Market Orientation on Business Profitability, Journal of Marketing, 54 (4). 20-35.

Oliver, Richard L. (1997), Satisfaction. A Behavioral Perspective on the Consumer. NewYork, USA: McGraw-Hill.

Reichheld, Frederick F. (1993), Loyalty-Based Management, Harvard Business Review, 71 (2). 64-73. 
Richardson, Paul S., Arun K. Jain, and Alan Dick (1996), Household Store Brand Proneness: A Framework, Journal of Retailing, 72 (2). 159-185.

Roth, Martin S. (1995), The Effects of Culture and Socioeconomics on the Performance of Global Brand Image Strategies, Journal of Marketing Research, 32 (May). 163-175.

Scheer, Lisa K. and Louis W. Stern (1992), The Effect of Influence Type and Performance Outcomes on Attitude toward the Influencer, Journal of Marketing Research, 29 (1). 128142.

Sharp, Byron and Anne Sharp (1997), Loyalty Programs and their Impact on Repeat-Purchase Loyalty Patterns, International Journal of Research in Marketing, 14 (5). 473-486.

Sheth, Jagdish N. and Atul Parvatiyar (1995), Relationship Marketing in Consumer Markets:

Antecedents and Consequences, Journal of the Academy of Marketing Science, 23 (4). 255271.

Shim, Soyeon and Mary Ann Eastlick (1998), The Hierarchical Influence of Personal Values on Mall Shopping Attitude and Behavior, Journal of Retailing, 74 (1). 139-160.

Sirohi, Niren, Edward W. McLaughlin, and Dick R. Wittink (1998), A Model of Consumer Perceptions and Store Loyalty Intentions for a Supermarket Retailer, Journal of Retailing, 74 (2). 223-245.

Solomon, Michael R., Carol Surprenant, John A. Czepiel, and Evelyn G. Guttman (1985), A

Role Theory Perspective on Dyadic Interactions: The Service Encounter, Journal of Marketing, 49 (1). 99-111.

Wakefield, Kirk L. and Julie Baker (1998), Excitement at the Mall: Determinants and Effects on Shopping Response, Journal of Retailing, 74 (4). 515-539.

Webster, Frederick E. (1992), The Changing Role of Marketing in the Corporation, Journal of Marketing, 56 (4). 1-17.

Wilkes, Robert E. (1992), A Structural Modeling Approach to the Measurement and Meaning of Cognitive Age, Journal of Consumer Research, 19 (September). 292-301.

Woodruff, Robert B. (1997), Customer Value: The Next Source for Competitive Advantage, Journal of the Academy of Marketing Science, 25 (2). 139-153.

Yoon, Carolyn (1997), Age Differences in Consumers' Processing Strategies: An Investigation of Moderating Influences, Journal of Consumer Research, 24 (December), 329-342. 
TABLE 1

Sample Sizes of Sub-Samples ${ }^{\text {(a) }}$

\begin{tabular}{|c|c|c|c|c|c|c|c|}
\hline & & US food & US app. & $\mathrm{N}$ food & $\mathrm{N}$ app. & B food & B app. \\
\hline & Total & 231 & 230 & 337 & 338 & 289 & $\overline{302}$ \\
\hline \multirow[t]{2}{*}{ Age } & Young & 186 & 156 & 198 & 184 & 138 & $\overline{91}$ \\
\hline & Old & 45 & 74 & 138 & 154 & 151 & 150 \\
\hline \multirow[t]{2}{*}{ Gen } & Female & 132 & 155 & 246 & 235 & 204 & 210 \\
\hline & Male & 91 & 75 & 91 & 103 & 85 & 91 \\
\hline \multirow[t]{2}{*}{ Enj } & Low & 74 & 76 & 110 & 113 & 100 & 101 \\
\hline & High & 82 & 89 & 119 & 134 & 101 & 96 \\
\hline \multirow[t]{2}{*}{$\operatorname{Rec}$} & Low & 67 & 70 & 114 & 116 & 81 & 62 \\
\hline & High & 82 & 95 & 121 & 130 & 118 & 144 \\
\hline \multirow[t]{2}{*}{ Aff } & Low & 89 & 71 & 124 & 127 & 78 & 103 \\
\hline & High & 97 & 78 & 104 & 126 & 129 & 77 \\
\hline \multirow[t]{2}{*}{ Inv } & Low & 89 & 75 & 96 & 116 & 97 & 108 \\
\hline & High & 112 & 76 & 104 & 104 & 107 & 92 \\
\hline \multirow[t]{2}{*}{ Crp } & Low & 88 & 75 & 106 & 110 & 107 & 102 \\
\hline & High & 91 & 78 & 116 & 128 & 100 & 110 \\
\hline
\end{tabular}


TABLE 2

Moderating Effects of Demographic Characteristics ${ }^{(a, b)}$

\begin{tabular}{lcc|cccc|ccc}
\hline & & \multicolumn{6}{|c|}{ Free paths to Cro } & \multicolumn{3}{c}{ Free paths from Cro } \\
\hline & & Equal & Com & Dif & Pe & Rew & Rs & Mit & Bl \\
\hline Age & US food & $1,316.34$ & $1,316.13$ & $1,315.56$ & $1,313.32$ & $1,315.52$ & $1,316.27$ & $1,315.88$ & $1,315.64$ \\
& US app. & $1,249.48$ & $1,249.46$ & $1,249.14$ & $1,248.98$ & $1,248.94$ & $1,248.94$ & $1,249.44$ & $1,245.07$ \\
N food & $1,408.38$ & $\underline{1,404.47}$ & $\underline{1,402.37}$ & $\underline{1,402.00}$ & $1,404.90$ & $1,407.35$ & $1,406.55$ & $1,407.93$ \\
N app. & $1,183.07$ & $1,183.07$ & $1,182.96$ & $1,181.09$ & $1,182.06$ & $1,183.07$ & $\underline{\underline{1,172.33}}$ & $1,181.43$ \\
B food & $1,072.33$ & $1,068.81$ & $1,071.21$ & $1,072.32$ & $1,071.73$ & $1,071.74$ & $1,069.64$ & $1,071.90$ \\
B app. & $1,438.54$ & $1,438.10$ & $1,438.08$ & $1,437.32$ & $1,438.41$ & $\underline{\underline{1,431.32}}$ & $\underline{1,424.78}$ & $1,435.89$ \\
\hline Gen & US food & $1,797.41$ & $1,794.72$ & $\underline{1,784.32}$ & $\underline{1,777.85}$ & $\underline{1,786.90}$ & $\underline{1,792.06}$ & $1,797.06$ & $1,797.08$ \\
US app. & $1,273.74$ & $1,273.55$ & $1,272.81$ & $1,273.73$ & $1,272.57$ & $1,273.72$ & $\underline{1,267.45}$ & $1,272.33$ \\
N food & 948.18 & 947.31 & 948.05 & 948.16 & 948.18 & 948.17 & 947.53 & 946.78 \\
N app. & 982.64 & 981.68 & 982.49 & 982.62 & 982.64 & 982.63 & 981.92 & 981.14 \\
B food & $1,032.70$ & $1,032.43$ & $1,032.65$ & $1,032.43$ & $1,032.44$ & $1,032.64$ & $1,031.45$ & $1,029.20$ \\
B app. & $1,023.21$ & $1,022.45$ & $1,022.65$ & $1,023.02$ & $1,021.79$ & $\underline{1,016.27}$ & $1,022.33$ & $1,022.75$ \\
\hline
\end{tabular}


TABLE 3

Moderating Effects of Personal Values ${ }^{(a, b)}$

\begin{tabular}{|c|c|c|c|c|c|c|c|c|c|}
\hline & & & \multicolumn{4}{|c|}{ Free paths to Cro } & \multicolumn{3}{|c|}{ Free paths from Cro } \\
\hline & & Equal & Com & Dif & $\overline{\mathrm{Pe}}$ & Rew & $\overline{\mathrm{Rs}}$ & Mit & $\overline{\mathrm{Bl}}$ \\
\hline \multirow[t]{6}{*}{$\operatorname{Rec}$} & US food & 1059.65 & 1057.05 & 1057.92 & 1058.64 & 1058.41 & 1049.73 & 1055.29 & 1059.63 \\
\hline & US app. & 1111.68 & 1111.66 & 1111.18 & 1111.68 & 1111.66 & 1110.01 & 1110.85 & 1111.41 \\
\hline & $\mathrm{N}$ food & 940.71 & 940.69 & 940.38 & 940.24 & $\underline{935.84}$ & $\underline{936.92}$ & 940.21 & 940.70 \\
\hline & $\mathrm{N}$ app. & 975.12 & 974.96 & 974.84 & 975.03 & 974.90 & 971.41 & 970.63 & 971.15 \\
\hline & B food & 861.02 & 860.63 & 860.22 & 860.12 & 859.47 & 860.41 & 861.00 & 860.44 \\
\hline & B app. & 1031.85 & 1031.55 & 1031.81 & 1031.79 & 1031.70 & 1031.82 & 1029.00 & 1030.46 \\
\hline \multirow[t]{6}{*}{ Aff } & US food & 1129.19 & 1129.06 & 1129.03 & 1129.13 & 1129.07 & $\underline{1119.04}$ & $\underline{1118.09}$ & 1127.72 \\
\hline & US app. & 1121.23 & 1119.63 & 1120.93 & 1119.67 & 1120.35 & 1115.49 & 1117.75 & 1114.88 \\
\hline & $\mathrm{N}$ food & 919.18 & 919.12 & $\underline{914.59}$ & 918.66 & $\underline{\underline{910.17}}$ & 916.74 & 919.07 & 917.08 \\
\hline & $\mathrm{N}$ app. & 982.33 & 982.23 & 982.29 & 981.92 & 981.81 & 979.15 & 980.93 & 977.34 \\
\hline & B food & 928.45 & 928.23 & 928.45 & 927.47 & 927.07 & 926.26 & 928.13 & 927.61 \\
\hline & B app. & 959.29 & 959.27 & 959.29 & 958.89 & 959.22 & 956.74 & 957.23 & 956.74 \\
\hline
\end{tabular}


TABLE 4

Moderating Effects of Shopping-Related Characteristics ${ }^{(\mathrm{a}, \mathrm{b})}$

\begin{tabular}{|c|c|c|c|c|c|c|c|c|c|}
\hline & & & \multicolumn{4}{|c|}{ Free paths to CRO } & \multicolumn{3}{|c|}{ Free paths from CRO } \\
\hline & & Equal & Com & Dif & $\overline{\mathrm{Pe}}$ & Rew & $\overline{\mathrm{Rs}}$ & Mit & $\overline{\mathrm{Bl}}$ \\
\hline \multirow[t]{6}{*}{ Inv } & US food & $1,611.21$ & $1,610.69$ & $1,610.48$ & $1,610.04$ & $1,610.13$ & $\underline{\underline{1,604.28}}$ & $1,607.67$ & $1,609.79$ \\
\hline & US app. & $1,113.35$ & $\underline{1,107.19}$ & $1,109.99$ & $1,111.44$ & $1,109.68$ & $1,110.58$ & $\underline{1,101.09}$ & $1,111.22$ \\
\hline & $\mathrm{N}$ food & $1,067.75$ & $1,067.46$ & $1,067.69$ & $1,067.74$ & $1,067.74$ & $1,067.52$ & $1,066.92$ & $1,067.43$ \\
\hline & $\mathrm{N}$ app. & 688.06 & - & 688.05 & - & - & 686.51 & 685.63 & 684.48 \\
\hline & B food & 954.40 & 953.65 & 954.21 & 953.53 & 954.26 & 953.95 & 950.90 & 953.77 \\
\hline & B app. & 929.33 & 927.72 & 929.31 & 929.32 & 929.32 & 929.06 & 924.18 & 927.99 \\
\hline \multirow[t]{6}{*}{ Srp } & US food & $1,229.29$ & $1,229.21$ & $1,229.02$ & $1,228.73$ & $1,229.22$ & $\underline{1,220.37}$ & $1,224.51$ & $\underline{1,222.29}$ \\
\hline & US app. & $1,162.95$ & $1,162.93$ & $1,162.75$ & $1,162.92$ & $1,162.95$ & $1,160.09$ & $1,157.58$ & $1,161.83$ \\
\hline & $\mathrm{N}$ food & 928.30 & 928.00 & 928.25 & 927.71 & 928.26 & 928.06 & 928.27 & 927.76 \\
\hline & $\mathrm{N}$ app. & $1,046.72$ & $1,045.98$ & $1,045.55$ & $1,044.21$ & $1,045.40$ & $1,045.57$ & $1,046.68$ & $1,046.60$ \\
\hline & B food & 886.40 & $\underline{\underline{879.33}}$ & 886.35 & 886.40 & 883.49 & $\underline{881.61}$ & $\underline{\underline{874.58}}$ & $\underline{882.43}$ \\
\hline & B app. & 975.33 & 974.94 & 975.07 & 975.18 & 972.80 & 972.80 & 975.30 & 974.45 \\
\hline \multirow[t]{6}{*}{ Enj } & US food & 1080.29 & 1080.09 & 1076.07 & 1078.73 & 1079.71 & 1057.99 & 1069.09 & 1074.65 \\
\hline & US app. & 1131.59 & 1130.50 & 1131.59 & 1129.27 & 1130.83 & 1130.64 & 1129.51 & 1130.07 \\
\hline & $\mathrm{N}$ food & 911.23 & 911.22 & 910.23 & 911.22 & 910.77 & 908.95 & 910.85 & 911.22 \\
\hline & $\mathrm{N}$ app. & 894.61 & - & 888.71 & 894.33 & 893.54 & 893.67 & 894.61 & 893.90 \\
\hline & B food & 856.31 & 854.65 & 855.91 & 855.89 & 852.27 & 855.80 & 852.55 & 856.23 \\
\hline & B app. & 892.61 & 890.70 & 891.03 & 889.80 & 890.69 & 890.49 & 890.02 & 892.46 \\
\hline
\end{tabular}




\section{TABLE 5}

Moderating Effects of Contextual Characteristics ${ }^{(a, b)}$

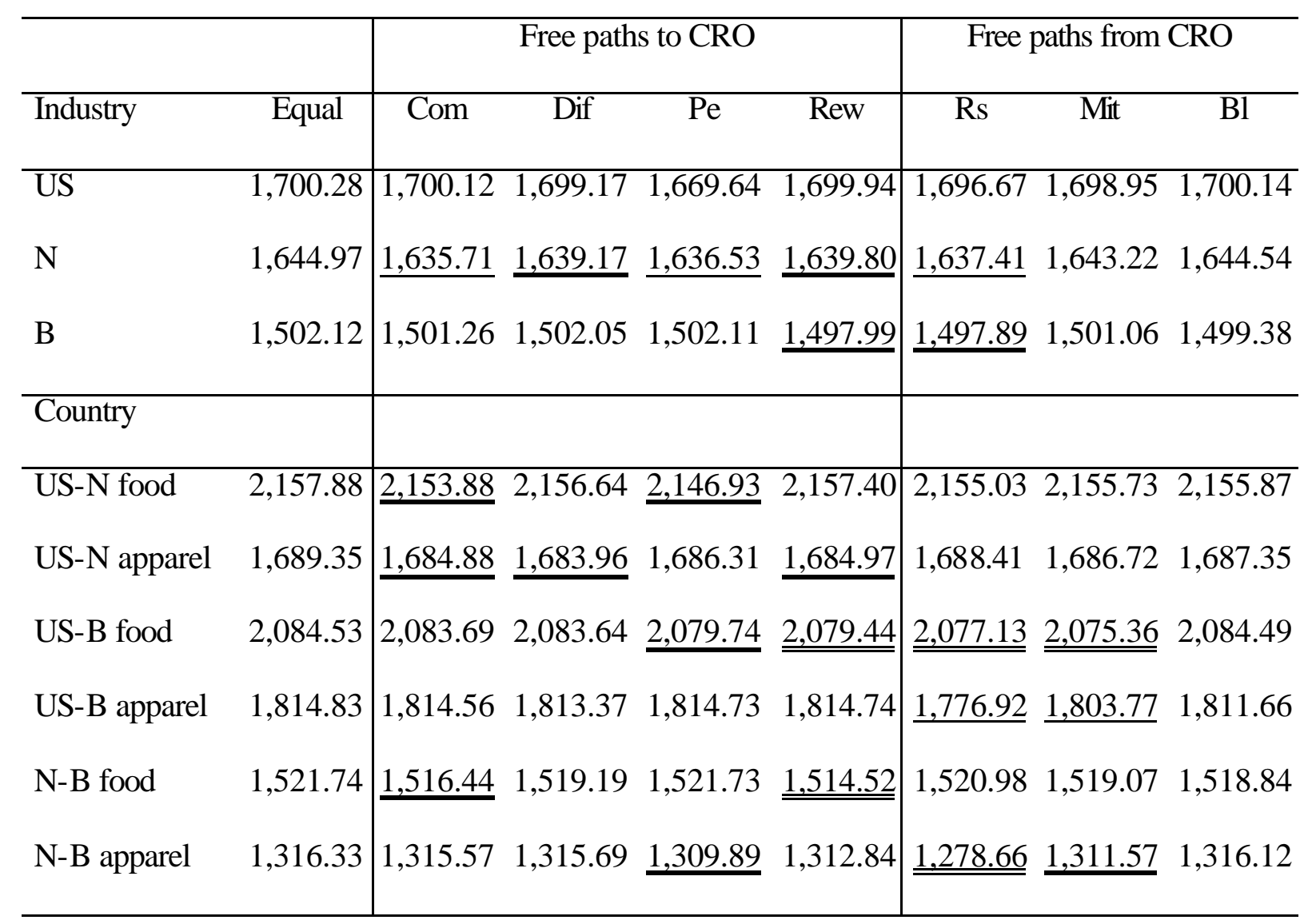


TABLE 6

Change in Path Coefficients (Demographic Characteristics) ${ }^{\text {(a) }}$

\begin{tabular}{|c|c|c|c|c|c|}
\hline Age & Path & Sample & Young & Old & Change \\
\hline & Com-Cro & $\mathrm{N}$ food & 0.21 & 0.00 & -0.21 \\
\hline & Dif-Cro & $\mathrm{N}$ food & 0.04 & -0.24 & -0.28 \\
\hline & Pe-Cro & $\mathrm{N}$ food & 0.44 & 0.19 & -0.25 \\
\hline & Cro-Rs & B apparel & 0.72 & 0.49 & -0.23 \\
\hline & Cro-Mit & $\mathrm{N}$ apparel & 0.65 & 0.81 & +0.16 \\
\hline & & B apparel & 0.74 & 0.38 & -0.36 \\
\hline & Cro-Bl & US apparel & 0.45 & 0.17 & -0.28 \\
\hline \multirow[t]{7}{*}{ Gen } & Path & Sample & Female & Male & Change \\
\hline & Dif-Cro & US food & 0.18 & -0.22 & -0.40 \\
\hline & Pe-Cro & US food & 0.68 & 0.36 & -0.32 \\
\hline & Rew-Cro & US food & -0.02 & -0.43 & -0.41 \\
\hline & Cro-Rs & US food & 0.72 & 0.53 & -0.19 \\
\hline & & B apparel & 0.60 & 0.31 & -0.29 \\
\hline & Cro-Mit & US apparel & 0.64 & 0.79 & +0.15 \\
\hline
\end{tabular}


TABLE 7

Change in Path Coefficients (Personal Values) ${ }^{\text {(a) }}$

\begin{tabular}{|c|c|c|c|c|c|}
\hline & Path & Sample & Low & High & Change \\
\hline \multirow[t]{7}{*}{$\operatorname{Rec}$} & Rew-Cro & $\mathrm{N}$ food & 0.27 & -0.03 & -0.30 \\
\hline & \multirow[t]{3}{*}{ Cro-Rs } & US food & 0.68 & 0.86 & +0.18 \\
\hline & & $\mathrm{N}$ food & 0.63 & 0.76 & +0.13 \\
\hline & & $\mathrm{N}$ apparel & 0.89 & 0.92 & +0.03 \\
\hline & \multirow[t]{2}{*}{ Cro-Mit } & US food & 0.47 & 0.69 & +0.22 \\
\hline & & $\mathrm{N}$ apparel & 0.68 & 0.80 & +0.12 \\
\hline & Cro-B1 & $\mathrm{N}$ apparel & 0.21 & 0.47 & +0.26 \\
\hline \multirow[t]{6}{*}{ Aff } & Dif-Cro & $\mathrm{N}$ food & 0.12 & -0.19 & -0.31 \\
\hline & Rew-Cro & $\mathrm{N}$ food & 0.34 & -0.08 & -0.42 \\
\hline & \multirow[t]{2}{*}{ Cro-Rs } & US food & 0.68 & 0.84 & +0.16 \\
\hline & & US apparel & 0.75 & 0.86 & +0.13 \\
\hline & Cro-Mit & US food & 0.45 & 0.74 & +0.29 \\
\hline & Cro-Bl & US apparel & 0.01 & 0.45 & +0.44 \\
\hline
\end{tabular}


TABLE 8

Change in Path Coefficients (Shopping-Related Characteristics) ${ }^{(a)}$

\begin{tabular}{|c|c|c|c|c|c|}
\hline & Path & Sample & Low & High & Change \\
\hline \multirow[t]{4}{*}{ Inv } & Com-Cro & US apparel & 0.14 & 0.43 & +0.29 \\
\hline & Cro-Rs & US food & 0.67 & 0.81 & +0.14 \\
\hline & Cro-Mit & US apparel & 0.52 & 0.80 & +0.28 \\
\hline & & B apparel & 0.38 & 0.63 & +0.25 \\
\hline \multirow[t]{8}{*}{ Srp } & Com-Cro & B food & 0.06 & 0.37 & +0.31 \\
\hline & Cro-Rs & US food & 0.59 & 0.79 & +0.20 \\
\hline & & B food & 0.40 & 0.64 & +0.24 \\
\hline & Cro-Mit & US food & 0.39 & 0.65 & +0.26 \\
\hline & & US apparel & 0.30 & 0.62 & +0.32 \\
\hline & & B food & 0.13 & 0.60 & +0.47 \\
\hline & Cro-Bl & US food & -0.10 & 0.32 & +0.42 \\
\hline & & B food & 0.21 & 0.47 & +0.26 \\
\hline \multirow[t]{7}{*}{ Enj } & Dif-Cro & US food & -0.35 & -0.05 & +0.30 \\
\hline & & $\mathrm{N}$ apparel & 0.17 & -0.05 & -0.22 \\
\hline & Rew-Cro & B food & 0.48 & 0.27 & -0.21 \\
\hline & Cro-Rs & US food & 0.51 & 0.84 & +0.33 \\
\hline & Cro-Mit & US food & 0.44 & 0.75 & +0.31 \\
\hline & & B food & 0.28 & 0.52 & +0.24 \\
\hline & Cro-Bl & US food & 0.05 & 0.43 & +0.38 \\
\hline
\end{tabular}




\section{TABLE 9}

Change in Path Coefficients (Contextual Characteristics) ${ }^{\text {(a) }}$

\begin{tabular}{llllrr}
\hline Industry & Path & Sample & Food & Apparel & Change \\
\hline Com-Cro & N & 0.06 & 0.27 & +0.21 \\
Dif-Cro & N & -0.07 & 0.11 & +0.18 \\
Pe-Cro & N & -0.21 & 0.39 & +0.60 \\
Rew-Cro & N & 0.16 & 0.31 & +0.15 \\
& B & 0.35 & 0.21 & -0.14 \\
Cro-Rs & N & 0.77 & 0.83 & +0.06 \\
& B & 0.63 & 0.52 & -0.11 \\
\hline
\end{tabular}




\section{TABLE 9 CONTINUED}

Change in Path Coefficients (Contextual Characteristics) ${ }^{\text {(a) }}$

\begin{tabular}{|c|c|c|c|c|c|c|}
\hline Country & Path & Sample & US & $\mathrm{N}$ & $\bar{B}$ & Change \\
\hline & \multirow[t]{3}{*}{ Com-Cro } & Food & 0.19 & 0.02 & & -0.17 \\
\hline & & Apparel & 0.15 & 0.28 & & +0.13 \\
\hline & & Food & & 0.06 & 0.24 & +0.18 \\
\hline & Dif-Cro & Apparel & -0.08 & 0.08 & & +0.16 \\
\hline & \multirow[t]{3}{*}{ Pe-Cro } & Food & 0.51 & 0.30 & & -0.21 \\
\hline & & Food & 0.36 & & 0.21 & -0.15 \\
\hline & & Apparel & & 0.39 & 0.23 & -0.16 \\
\hline & \multirow[t]{3}{*}{ Rew-Cro } & Apparel & 0.09 & 0.22 & & +0.13 \\
\hline & & Food & 0.28 & & 0.43 & +0.15 \\
\hline & & Food & & 0.26 & 0.45 & +0.19 \\
\hline & \multirow[t]{3}{*}{ Cro-Rs } & Food & 0.75 & & 0.64 & -0.11 \\
\hline & & Apparel & 0.81 & & 0.55 & -0.26 \\
\hline & & Apparel & & 0.81 & 0.59 & -0.22 \\
\hline & \multirow[t]{3}{*}{ Cro-Mit } & Food & 0.65 & & 0.47 & -0.18 \\
\hline & & Apparel & 0.68 & & 0.49 & -0.19 \\
\hline & & Apparel & & 0.67 & 0.55 & -0.12 \\
\hline
\end{tabular}


FIGURE 1

Conceptual Model

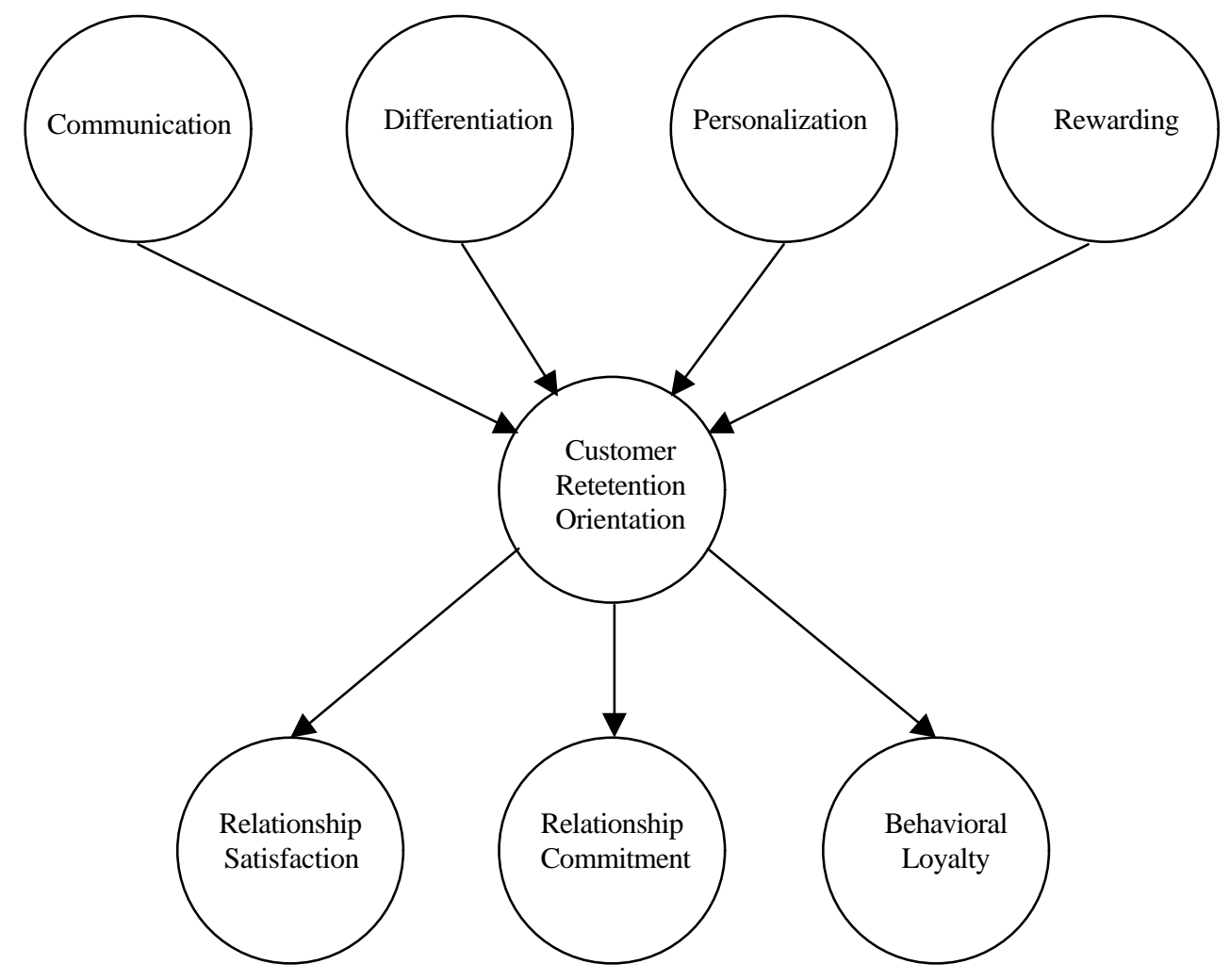




\section{APPENDIX}

Internal Consistency of Constructs (c)

\begin{tabular}{|c|c|c|c|c|c|c|c|c|c|c|c|c|c|}
\hline \multirow{3}{*}{ Construct } & \multirow[b]{3}{*}{ Items } & \multicolumn{6}{|c|}{ Food } & \multicolumn{6}{|c|}{ Apparel } \\
\hline & & \multicolumn{2}{|c|}{ US } & \multicolumn{2}{|c|}{$\mathrm{N}$} & \multicolumn{2}{|c|}{$\mathrm{B}$} & \multicolumn{2}{|c|}{ US } & \multicolumn{2}{|c|}{$\mathrm{N}$} & \multicolumn{2}{|c|}{$\mathrm{B}$} \\
\hline & & $\alpha$ & $\mathrm{i}$ & $\alpha$ & $\mathrm{i}$ & $\alpha$ & $\mathrm{i}$ & $\alpha$ & $\mathrm{i}$ & $\alpha$ & $\mathrm{i}$ & $\alpha$ & $\mathrm{i}$ \\
\hline Communication & $\begin{array}{l}\text { This store often sends mailings } \\
\text { to regular customers } \\
\text { This store keeps regular } \\
\text { customers informed through } \\
\text { mailings } \\
\text { This store often informs regular } \\
\text { customers through brochures }\end{array}$ & 0.88 & $\begin{array}{l}0.66 \\
0.83\end{array}$ & 0.75 & $\begin{array}{l}0.50 \\
0.65\end{array}$ & 0.82 & $\begin{array}{l}0.68 \\
0.79\end{array}$ & 0.93 & $\begin{array}{l}0.82 \\
0.87\end{array}$ & 0.94 & $\begin{array}{l}0.85 \\
0.86\end{array}$ & 0.93 & $\begin{array}{l}0.86 \\
0.87\end{array}$ \\
\hline Differentiation & $\begin{array}{l}\text { This store makes greater efforts } \\
\text { for regular customers than for } \\
\text { non-regular customers } \\
\text { This store offers better service to } \\
\text { regular customers than to non- } \\
\text { regular customers } \\
\text { This store does more for regular } \\
\text { customers than for non-regular } \\
\text { customers }\end{array}$ & 0.90 & 0.80 & 0.79 & 0.70 & 0.91 & 0.85 & 0.88 & 0.82 & 0.86 & 0.73 & 0.86 & 0.75 \\
\hline Personalization & $\begin{array}{l}\text { This store takes the time to } \\
\text { personally get to know regular } \\
\text { customers } \\
\text { This store often holds personal } \\
\text { conversations with regular } \\
\text { customers } \\
\text { This store often inquires about } \\
\text { the personal welfare of regular } \\
\text { customers }\end{array}$ & 0.89 & 0.82 & 0.87 & $\begin{array}{l}0.73 \\
0.79\end{array}$ & 0.89 & 0.79 & 0.89 & 0.83 & 0.89 & 0.76 & 0.83 & 0.68 \\
\hline
\end{tabular}


APPENDIX CONTINUED

Internal Consistency of Constructs (c)

\begin{tabular}{|c|c|c|c|c|c|c|c|c|c|c|c|c|c|}
\hline \multirow{3}{*}{ Construct } & \multirow[b]{3}{*}{ Items } & \multicolumn{6}{|c|}{ Food } & \multicolumn{6}{|c|}{ Apparel } \\
\hline & & \multicolumn{2}{|c|}{ US } & \multicolumn{2}{|c|}{$\mathrm{N}$} & \multicolumn{2}{|c|}{ B } & \multicolumn{2}{|c|}{ US } & \multicolumn{2}{|c|}{$\mathrm{N}$} & \multicolumn{2}{|c|}{$\mathrm{B}$} \\
\hline & & $\alpha$ & $\mathrm{i}$ & $\alpha$ & $\mathrm{i}$ & $\alpha$ & $\mathrm{i}$ & $\alpha$ & $\mathrm{i}$ & $\alpha$ & $\mathrm{i}$ & $\alpha$ & $\mathrm{i}$ \\
\hline Rewarding & $\begin{array}{l}\text { This store rewards regular } \\
\text { customers for their patronage } \\
\text { This store offers regular } \\
\text { customers something extra } \\
\text { because they keep buying there } \\
\text { This store really cares about } \\
\text { keeping regular customers }\end{array}$ & 0.87 & $\begin{array}{l}0.71 \\
0.78\end{array}$ & 0.77 & $\begin{array}{l}0.62 \\
0.61\end{array}$ & 0.79 & $\begin{array}{l}0.70 \\
0.66\end{array}$ & 0.91 & $\begin{array}{l}0.80 \\
0.84\end{array}$ & 0.86 & $\begin{array}{l}0.75 \\
0.78\end{array}$ & 0.85 & $\begin{array}{l}0.76 \\
0.75\end{array}$ \\
\hline $\begin{array}{l}\text { Customer } \\
\text { retention } \\
\text { orientation }\end{array}$ & $\begin{array}{l}\text { This store makes efforts to } \\
\text { increase regular customer's } \\
\text { loyalty } \\
\text { This store makes various efforts } \\
\text { to improve its tie with regular } \\
\text { customers } \\
\text { This store really cares about } \\
\text { keeping regular customers }\end{array}$ & 0.92 & 0.88 & 0.86 & 0.77 & 0.89 & 0.80 & 0.93 & 0.84 & 0.90 & 0.82 & 0.87 & $\begin{array}{l}0.70 \\
0.79\end{array}$ \\
\hline $\begin{array}{l}\text { Relationship } \\
\text { satisfaction }\end{array}$ & $\begin{array}{l}\text { As a regular customer, I have a } \\
\text { high quality relationship with } \\
\text { this store } \\
\text { I am happy with the efforts this } \\
\text { store is making towards regular } \\
\text { customers like me } \\
\text { I am satisfied with the } \\
\text { relationship I have with this } \\
\text { store }\end{array}$ & 0.85 & $\begin{array}{l}0.74 \\
0.73\end{array}$ & 0.76 & $\begin{array}{l}0.57 \\
0.56\end{array}$ & 0.82 & 0.67 & 0.88 & 0.76 & 0.83 & 0.72 & 0.76 & $\begin{array}{l}0.64 \\
0.60\end{array}$ \\
\hline
\end{tabular}


APPENDIX CONTINUED

Internal Consistency of Constructs (c)




APPENDIX CONTINUED

Internal Consistency of Constructs (c)

\begin{tabular}{|c|c|c|c|c|c|c|c|c|c|c|c|c|c|}
\hline \multirow{3}{*}{ Construct } & \multirow[b]{3}{*}{ Items } & \multicolumn{6}{|c|}{ Food } & \multicolumn{6}{|c|}{ Apparel } \\
\hline & & \multicolumn{2}{|c|}{ US } & \multicolumn{2}{|c|}{$\mathrm{N}$} & \multicolumn{2}{|c|}{$\mathrm{B}$} & \multicolumn{2}{|c|}{ US } & \multicolumn{2}{|c|}{$\mathrm{N}$} & \multicolumn{2}{|c|}{$\mathrm{B}$} \\
\hline & & $\alpha$ & $\mathrm{i}$ & $\alpha$ & $\mathrm{i}$ & $\alpha$ & $\mathrm{i}$ & $\alpha$ & $\mathrm{i}$ & $\alpha$ & $\mathrm{i}$ & $\alpha$ & $\mathrm{i}$ \\
\hline Social affiliation & $\begin{array}{l}\text { Generally, I am someone who } \\
\text { likes to seek contact with others } \\
\text { Generally, I am someone who } \\
\text { has no difficulty "mingling" in a } \\
\text { group } \\
\text { Generally, I am someone who, } \\
\text { given the chance, seeks contact } \\
\text { with others }\end{array}$ & 0.85 & $\begin{array}{l}0.62 \\
0.78\end{array}$ & 0.75 & $\begin{array}{l}0.40 \\
0.68\end{array}$ & 0.77 & $\begin{array}{l}0.47 \\
0.64\end{array}$ & 0.89 & $\begin{array}{l}0.68 \\
0.85\end{array}$ & 0.71 & $\begin{array}{l}0.33 \\
0.61\end{array}$ & 0.71 & $\begin{array}{l}0.41 \\
0.56\end{array}$ \\
\hline $\begin{array}{l}\text { Product category } \\
\text { involvement }\end{array}$ & $\begin{array}{l}\text { Generally, I am someone who } \\
\text { finds it important what clothes } \\
\text { he or she buys } \\
\text { Generally, I am someone who is } \\
\text { interested in the kind of clothing } \\
\text { he or she buys } \\
\text { Generally, I am someone for } \\
\text { whom it means a lot what } \\
\text { clothes he or she buys }\end{array}$ & 0.79 & 0.69 & 0.91 & 0.81 & 0.86 & 0.79 & 0.86 & 0.77 & 0.84 & 0.74 & 0.87 & 0.75 \\
\hline $\begin{array}{l}\text { Store relationship } \\
\text { proneness }\end{array}$ & $\begin{array}{l}\text { Generally, I am someone who } \\
\text { likes to be a regular customer of } \\
\text { an apparel store } \\
\text { Generally, I am someone who } \\
\text { wants to be a steady customer of } \\
\text { the same apparel store } \\
\text { Generally, I am someone who is } \\
\text { willing to 'to go the extra mile' } \\
\text { to buy at the same apparel store }\end{array}$ & 0.87 & $\begin{array}{l}0.78 \\
0.76\end{array}$ & 0.88 & 0.77 & 0.87 & 0.70 & 0.89 & 0.80 & 0.89 & 0.78 & 0.85 & $\begin{array}{l}0.76 \\
0.72\end{array}$ \\
\hline
\end{tabular}


APPENDIX CONTINUED

Internal Consistency of Constructs (c)

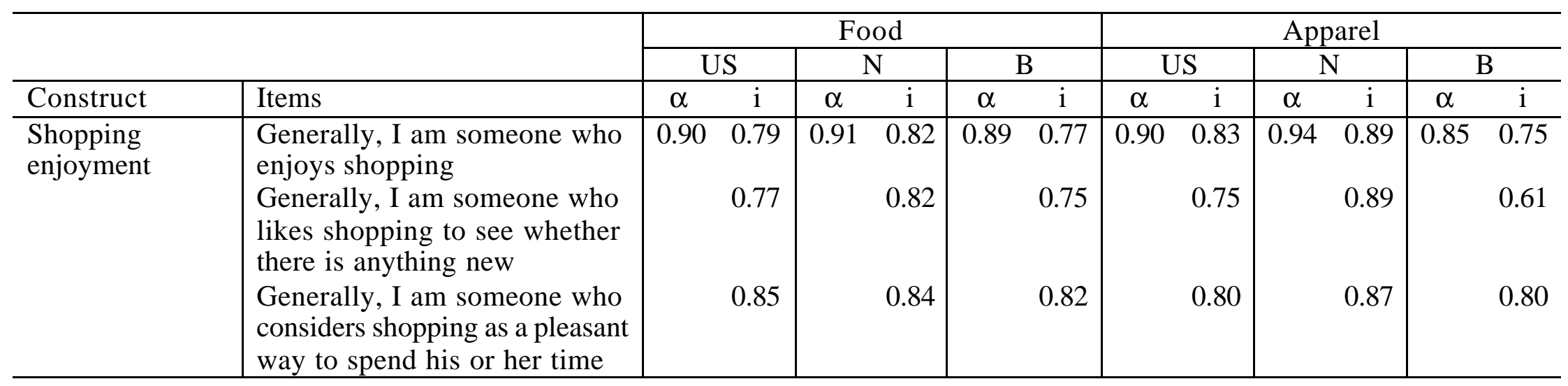




\section{NOTES}

a. The following abbreviations were used: $\mathrm{Com}=$ communication, $\mathrm{Dif}=$ differentiation, $\mathrm{Pe}=$ personalization, Rew $=$ rewarding, Cro $=$ customer retention orientation, $\mathrm{Rs}=$ relationship satisfaction, Mit $=$ relationship commitment, $\mathrm{Bl}=$ behavioral loyalty, $\mathrm{Rec}=$ social recognition, Aff = social affiliation, $\mathrm{Inv}=$ product category involvement, $\mathrm{Srp}=$ store relationship proneness, Enj = shopping enjoyment, US = United States, $\mathrm{N}=$ the Netherlands, $\mathrm{B}=$ Belgium. Double underlined estimates: $\mathrm{p}<0.01$, single underlined estimates: $\mathrm{p}<0.05$.

b. Numbers presented in italics refer to contingency factors that are significantly associated with other contingency factors in the specific sample for the specific path examined. In each sub-sample, we examined whether contingency factors could be considered as independent using Pearson correlation coefficients, chi square coefficients, and F values based upon oneway ANOVA (95\% confidence interval). This is important in order to be able to attribute significant moderator effects to one specific contingency variable. For example, if "store relationship proneness" and "product category involvement" correlate and if both moderate relationship marketing effectiveness, it is hard to determine which one causes the moderating effect. Evidently, if only one of two variables related to each other significantly moderates relationship marketing effectiveness, the moderating effect can be safely attributed to this variable. The problem only occurred in the US samples for contingency factors moderating the relationships between customer relationship orientation and relationship satisfaction and relationship commitment.

c. The formulation of the items is based on the apparel samples. In the food samples, the word 'apparel store' is replaced by supermarket. The following abbreviations were used: $\alpha=$ Cronbach's alpha coefficient, $\mathrm{i}=$ item-to-total correlation. 